\title{
PENALARAN ANALOGI SISWA SMA DALAM PENGAJUAN MASALAH SETELAH SOLUSI
}

\section{Agung Prasetyo}

Pendidikan Matematika, FMIPA, Universitas Negeri Surabaya, e-mail: agung.17030174025@mhs.unesa.ac.id

\author{
Abdul Haris Rosyidi \\ Pendidikan Matematika, FMIPA, Universitas Negeri Surabaya, e-mail: abdulharis@unesa.ac.id
}

\begin{abstract}
Abstrak
Penelitian ini bertujuan untuk mendeskripsikan penalaran analogi siswa SMA dalam pengajuan masalah setelah solusi. Subjek penelitian terdiri dari 3 siswa terpilih di kelas X SMAN 1 Gresik tahun ajaran 2020/2021 semester ganjil. Subjek dipilih berdasarkan kriteria kemiripan masalah yang diajukan dengan masalah sumber, yaitu: kemiripan permukaan (surface similarity) dan kemiripan struktur (structural similarity). Selanjutnya, dilakukan wawancara untuk menggali informasi mengenai penalaran analogi yang terlibat dalam pengajuan masalah. Hasil penelitian menunjukkan bahwa, dalam mengajukan masalah siswa cenderung mengadaptasi informasi di permukaan maupun struktur masalah sumber. Meskipun ketika mengadaptasi struktur masalah sumber, siswa cenderung memerlukan waktu yang lebih lama atau ia mengetahuinya secara tidak langsung saat memecahkan masalah sumber. Pada fase persiapan, siswa mampu memahami maksud masalah sumber dengan benar. Pada fase inkubasi, siswa cenderung mampu mengidentifikasi informasi di permukaan masalah sumber dengan benar. Sementara itu, struktur masalah sumber dapat diidentifikasi oleh siswa, hanya saja siswa memerlukan waktu yang lebih lama atau ia mengetahuinya secara tidak langsung ketika memecahkan masalah sumber. Pada fase iluminasi, siswa cenderung mengadaptasi informasi di permukaan masalah sumber secara langsung atau mengubah struktur menjadi lebih sederhana. Pada fase verifikasi, siswa cenderung memastikan kebenaran masalah yang diajukan dengan melihat masalah sumber dan pemecahan masalah yang diajukan. Keterampilan siswa dalam mengadaptasi informasi di permukaan maupun struktur masalah sumber mengindikasikan kemiripan masalah yang diajukan dengan masalah sumber, sehingga penalaran analogi membantu siswa dalam mengajuan masalah. Oleh karena itu, guru dapat melatihkan siswa untuk mengajukan masalah berbantuan penalaran analogi.
\end{abstract}

Kata Kunci: Pengajuan Masalah Setelah Solusi, Penalaran Analogi, Kemiripan Permukaan, Kemiripan Struktural.

\begin{abstract}
This study aims to describe the analogical reasoning of high school students in post solution problem posing. The research subjects consisted of 3 selected students in class X SMAN 1 Gresik in the odd semester of 2020/2021. Subjects were selected based on the criteria for the similarity of the problem posed with the problem of the source, namely: surface similarity and structural similarity. Furthermore, interviews were conducted to obtain information about analogical reasoning involved in problem posing. The results showed that, in posing a problem, students tended to adapt information on the surface and structure of the problem source. Even when adapting the structure of the source problem, students tend to take a longer time or they knows it indirectly when solving the source problem. In the preparation phase, students are able to understand the meaning of the source problem correctly. In the incubation phase, students tend to be able to correctly identify information on the surface of the source problem. Meanwhile, the structure of the source problem can be identified by students, it's just that students need more time or they know it indirectly when solving the source problem. In the illumination phase, students tend to adapt the information on the surface of the source problem directly or change the structure to be simpler. In the verification phase, students tend to ensure the correctness of the problems posed by looking at the source problem and solving the problems posed. Students' skills in adapting information on the surface and structure of the source problem indicate the similarity of the problem posed to the source problem, so analogy reasoning helps students pose problems. Therefore, teachers can train students to pose problems assisted by analogical reasoning.
\end{abstract}

Keywords: Problem Posing Post Solution, Analogical Reasoning, Surface Similarity, Structural Similarity. 


\section{PENDAHULUAN}

Ketika siswa kesulitan dalam menyelesaikan suatu masalah maka siswa tersebut dapat mengingat kembali masalah serupa yang pernah dijumpainya. Siswa dapat menerapkan prosedur penyelesaian masalah sebelumnya ke masalah baru, metode ini disebut penalaran analogi (Gentner dan Smith dalam Hostetter dkk., 2019). Penalaran analogi bergantung pada pengetahuan atau masalah yang sudah dipelajari sebelumnya (English, 2004). Penalaran analogi didefinisikan sebagai kemampuan mengamati, dan menemukan kemiripan antar struktur (Lee dan Sriraman, 2011), serta merujuk pada keterampilan kognitif yang menjadi dasar proses mempersepsikan kemiripan struktur antar masalah (Richland, 2016). Inti dari penalaran analogi adalah menemukan masalah sumber yang mirip dengan masalah target dan memetakan solusi dari masalah sumber ke masalah target (Lee, 1992).

Penalaran analogi terfokus pada kemiripan relasional (struktur yang mirip) antara masalah sumber dan masalah target berdasarkan hubungan yang ada (Boteanu dan Chernova, 2015). Kemiripan tersebut dapat diidentifikasi berdasarkan hubungan yang tampak maupun hubungan yang masih belum tampak. Identifikasi kemiripan antara masalah sumber dan masalah target diklasifikasikan menjadi dua jenis yaitu surface similarity (kemiripan permukaan) dan structural similarity (kemiripan struktur) (Holyoak dan Koh, 1987). Kemiripan permukaan merujuk pada kemiripan antara masalah sumber dan masalah target yang tampak secara permukaan, sedangkan kemiripan struktur merujuk pada kemiripan masalah sumber dengan masalah target yang bersifat konseptual seperti proses atau fungsinya (Forsyth, 2018).

Perbedaan kemiripan permukaan dan kemiripan struktur bergantung pada tampilan masalah, apakah relevan atau tidak apabila digunakan untuk memecahkan masalah target (Holyoak dan Koh, 1987). Kemiripan permukaan menitikberatkan pada kemiripan tampilan masalah di permukaan. Suatu masalah dikatakan tidak mirip secara permukaan (surface dissimilarity) apabila perubahan tampilan masalah tetap dapat digunakan untuk menyelesaikan masalah target (Holyoak, 1984). Sementara itu, kemiripan struktur menitikberatkan pada kemiripan struktur antar masalah. Suatu masalah dikatakan tidak mirip secara struktur (structural dissimilarity) apabila terdapat perbedaan struktur sehingga mengubah hubungan sebab akibat antara masalah sumber dan masalah target (Holyoak dan Koh, 1987).

Penalaran analogi diperlukan dalam pemecahan masalah, khususnya masalah visual (Lovett, 2017). Menurut Holyoak dan Hummel dalam Kristayulita dkk. (2020), siswa dapat menyelesaikan masalah dengan mengidentifikasi kemiripan masalah sumber dan masalah target melalui penalaran analogi. Bahkan, penalaran analogi dijadikan sebuah strategi baru dalam memecahkan masalah. Strategi pemecahan masalah menggunakan penalaran analogi disebut analogical problem solving (Israel, 2019). Masalah dapat dipecahkan dengan mengidentifikasi masalah target kemudian dikaitkan dengan masalah (sumber) serupa yang diingat, secara lengkap prosesnya menerapkan penalaran analogi (Assmuss dkk., 2014). Berdasarkan uraian tersebut, dapat disimpulkan bahwa penalaran analogi dan pemecahan masalah berkaitan erat.

Pemecahan masalah memiliki hubungan yang erat dengan pengajuan masalah (Xie dan Masingila, 2017). Dalam sebuah penelitian yang melibatkan guru, Kar dkk. (2010) menemukan suatu hubungan yang erat antara pemecahan masalah dan pengajuan masalah. Hal ini diindikasikan oleh hubungan antara keterampilan pemecahan masalah dengan banyak masalah yang diajukan. Lebih lanjut, dalam sebuah penelitian yang melibatkan siswa, Cai dan Hwang (2002) menemukan bahwa kemampuan pemecahan masalah dan pengajuan masalah berkaitan erat. Pada umumnya, siswa yang mampu menyelesaikan masalah dengan benar dapat mengajukan masalah lebih banyak dan lebih rumit (Xie dan Masingila, 2017). Oleh karena itu, pemecahan masalah dan pengajuan masalah berkaitan erat. Secara khusus, pengajuan masalah ternyata juga memiliki keterkaitan dengan penalaran analogi. Ketika mengajukan masalah, masalah yang diajukan dapat dianalogikan terlebih dahulu dengan masalah sumber, baik secara struktur (karena terdapat kemiripan informasi) maupun prosedur penyelesaiannya (Cruz dkk., 2016). Bahkan menurut Stiff dan Curcio dalam Siswono (2004), pengajuan masalah adalah salah satu bentuk penalaran analogi. Dalam pengajuan masalah salah satu faktor yang berpengaruh besar adalah penalaran analogi (Choe dan Mann, 2012). Oleh karena itu, berdasarkan keterkaitan antara pemecahan masalah dan pengajuan masalah, serta peran penting penalaran analogi dalam pemecahan masalah maka diduga penalaran analogi juga berperan penting dalam pengajuan masalah.

Pengajuan masalah menjadi salah satu topik yang berperan penting dalam pembelajaran matematika baik bagi siswa maupun guru (Rafi dan Sugiman, 2019). Dalam penelitiannya, Rohmatin (2014) menemukan bahwa pengajuan dan pemecahan masalah dapat meningkatkan kemampuan berpikir kritis siswa. Senada dengan itu, Purnomo dkk. (2015) menemukan bahwa pengajuan masalah dapat meningkatkan kemampuan siswa dalam memecahkan masalah. Selain itu, melalui pelatihan pengajuan masalah Xia dkk. (2008) menemukan bahwa pengajuan masalah berguna untuk meningkatkan kemampuan siswa dalam mempelajari matematika. Berdasarkan riset tersebut, tampak bahwa pengajuan 
masalah memiliki banyak manfaat dalam pembelajaran matematika. Di sisi lain, meskipun diklaim memiliki berbagai kelebihan namun sebagian siswa ternyata masih kesulitan dalam menyelesaikan tugas berbasis pengajuan masalah. Dalam penelitiannya yang melibatkan siswa SMA, Komalasari dkk. (2018) menemukan bahwa sebagian besar subjek penelitiannya gagal mengajukan masalah khususnya ketika merepresentasikan masalah ke bentuk lain yang memiliki makna sama. Serupa dengan itu, Afifah (2015) menemukan bahwa sebagian siswa mampu mengajukan masalah namun masalah tersebut justru tidak dapat diselesaikan. Pengajuan masalah dirasa sulit karena menuntut siswa berpikir kreatif ketika mengontruksi suatu masalah. Salah satu cara yang diduga membantu siswa dalam mengajukan masalah adalah menggali informasi yang pernah diperoleh kemudian diadaptasi untuk mengontruksi masalah. Oleh karena itu, penalaran analogi diduga dapat membantu siswa ketika mengajukan masalah.

Pengajuan masalah diklasifikasikan menjadi 3 macam yaitu sebelum solusi (pre solution), di dalam solusi (within solution), dan setelah solusi (post solution) (Silver dan Cai, 1996). Penelitian ini terfokus pada pengajuan masalah setelah solusi. Sebelum mengajukan masalah siswa diminta menyelesaikan masalah terlebih dahulu. Proses pengajuan masalah terdiri dari empat langkah yaitu persiapan (preparation), inkubasi (incubation), iluminasi (illumination), dan verifikasi (verification) (Wallas dalam Siswono, 2004). Pada tahap persiapan siswa berusaha mendapatkan ide sebelum mengajukan masalah. Selanjutnya pada tahap inkubasi siswa mencoba berpikir untuk menemukan ide. Pada tahap iluminasi siswa mulai memunculkan dan mengelola ide untuk mengajukan masalah. Terakhir pada tahap verifikasi, siswa mengajukan masalah dan memeriksa kembali.

Proses penalaran analogi dalam pengajuan masalah akan ditinjau berdasarkan strategi penalaran analogi dalam menyelesaikan masalah yang diajukan oleh English (2004). Strategi tersebut diilustrasikan dalam gambar 1 .

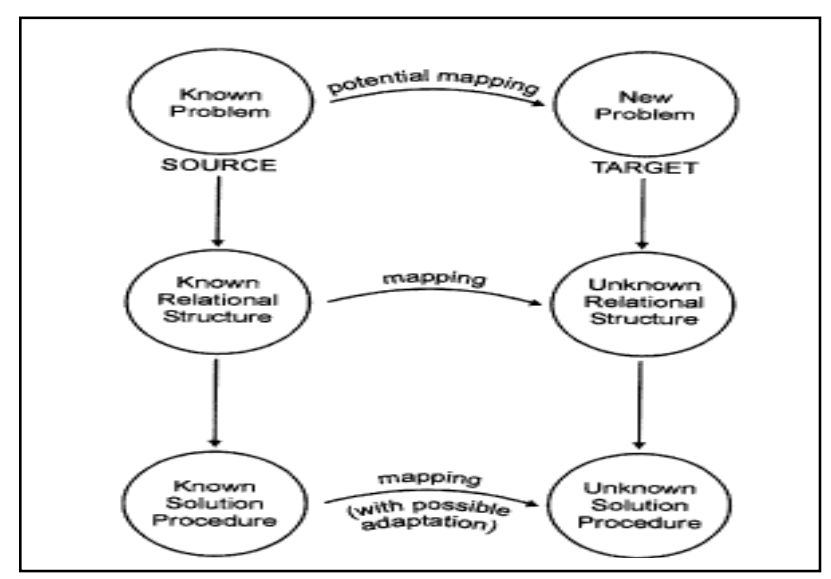

Gambar 1. Proses Penalaran Analogi dalam Pemecahan Masalah
Secara implisit, English (2004) menyatakan bahwa ketika memecahkan masalah, siswa dapat mengaitkan dengan masalah yang pernah dijumpainya. Menganalogikan hal tersebut, ketika mengajukan masalah melalui penalaran analogi ada tiga cara yang dapat ditempuh, yaitu: masalah sumber diadaptasi langsung untuk mengkontruksi masalah target; masalah sumber diidentifikasi struktur masalahnya terlebih dahulu, kemudian diadaptasi untuk membangun struktur masalah target; masalah sumber diidentifikasi struktur dan prosedur penyelesaiannya terlebih dahulu, selanjutnya prosedur penyelesaian masalah sumber diadaptasi untuk membangun masalah target.

Penelitian mengenai penalaran analogi cukup banyak ditemukan, misalnya: Analogi dan berpikir tingkat tinggi: sebagai contoh dalam pembelajaran matematika (Richland, 2016); Pengkajian kesalahan penalaran analogi siswa prakuliah dalam memecahkan masalah berdasarkan komponen penalaran analogi (Manuaba dkk., 2017); Perbedaan individual dalam transfer analogi secara spontan (Kubricht dkk., 2017); Kontribusi unik penalaran analogis verbal dan penalaran matriks nonverbal untuk pemecahan masalah matematika dan sains di masa remaja (Brookman dkk., 2019). Di ranah penalaran analogi, penelitian mengenai pengajuan masalah masih jarang ditemui. Beberapa penelitian mengenai penalaran analogi yang berkaitan dengan pengajuan masalah misalnya: penalaran analogi dalam pengajuan masalah matematika (Cruz dkk., 2016); Pengajuan masalah matematika melalui analogi: menemukan hubungan antara teorema Walter dan Morley (Cruz, 2020). Di antara berbagai macam penelitian mengenai penalaran analogi, masih belum ada yang melihat keterkaitannya dengan pengajuan masalah setelah solusi. Oleh karena itu, peneliti tertarik untuk melakukan penelitian yang bertujuan untuk mendeskripsikan penalaran analogi siswa SMA dalam pengajuan masalah setelah solusi.

\section{METODE}

Penelitian ini menggunakan metode deskriptif kualitatif yang bertujuan untuk mendeskripsikan penalaran analogi siswa SMA dalam pengajuan masalah setelah solusi. Calon subjek penelitian terdiri dari 43 siswa kelas X SMAN 1 Gresik tahun ajaran 2020/2021 semester ganjil. Instrumen penelitian yang digunakan berupa tes tertulis dan wawancara. Tes tertulis terdiri dari satu soal pemecahan masalah, dan sebuah soal pengajuan masalah setelah solusi beserta pemecahan masalahnya. Secara rinci, soal tes tersebut dapat dicermati di gambar 2 . 


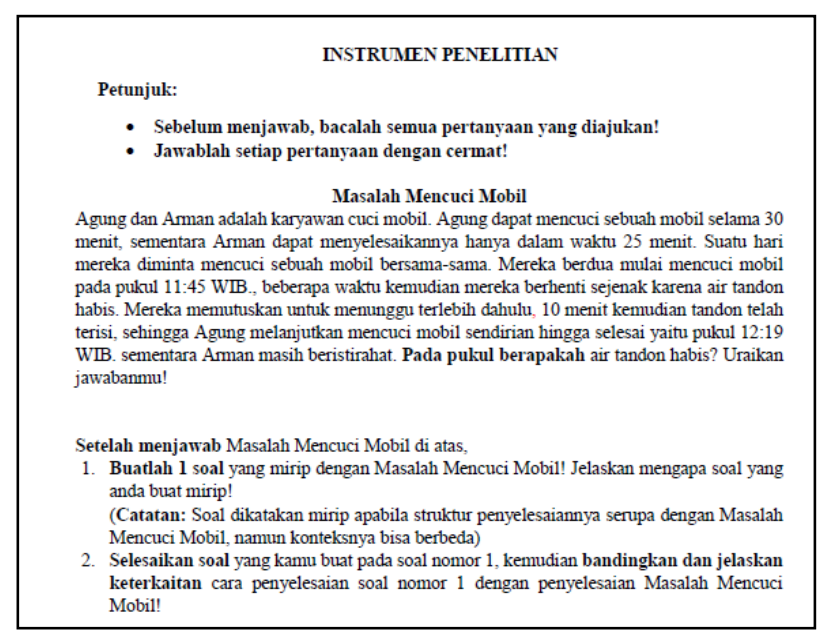

Gambar 2. Instrumen Penelitian

Hasil tes tertulis dianalisa, kemudian dipilih 3 subjek untuk diwawancarai berdasarkan informasi yang tertulis di lembar jawaban. Wawancara dilakukan untuk mengetahui penalaran analogi yang terlibat ketika subjek mengajukan masalah. Pemilihan subjek mengacu pada kriteria masalah yang diajukan. Kriteria masalah tersebut yaitu: masalah yang diajukan memiliki derajat kemiripan tinggi baik permukaan maupun struktur (subjek S1); masalah yang diajukan memiliki derajat kemiripan tinggi secara permukaan namun lemah secara struktur (subjek S2); masalah yang diajukan memiliki derajat kemiripan rendah baik permukaan maupun struktur (subjek S3). Sebelum mengajukan masalah, subjek akan diminta menyelesaikan sebuah masalah terlebih dahulu. Masalah yang diselesaikan tersebut, dijadikan sebagai masalah sumber untuk mengkontruksi/mengajukan masalah baru (target). Pemecahan masalah yang diberikan akan dilihat sekilas terlebih dahulu, sebab pemecahan masalah menjadi dasar dalam mengajukan masalah setelah solusi. Penalaran analogi yang terlibat dalam pengajuan masalah yang dilakukan oleh tiga subjek tersebut akan diidentifikasi berdasarkan tabel 1 .

Tabel 1. Pengajuan Masalah melalui Penalaran Analogi

\begin{tabular}{|c|l|}
\hline \multicolumn{2}{|c|}{ Proses yang Dilakukan Subjek } \\
\hline $\begin{array}{c}\text { Langkah } \\
\text { Pengajuan } \\
\text { Masalah }\end{array}$ & \multicolumn{1}{|c|}{ Penalaran Analogi yang } \\
Terlibat
\end{tabular}

\begin{tabular}{|c|l|}
\hline \multicolumn{3}{|c|}{ Proses yang Dilakukan Subjek } \\
\hline $\begin{array}{c}\text { Langkah } \\
\text { Pengajuan } \\
\text { Masalah }\end{array}$ & \multicolumn{3}{|c|}{ Penalaran Analogi yang } \\
Terlibat \\
\hline Inkubasi & $\begin{array}{l}\text { Siswa mengidentifikasi } \\
\text { informasi yang ada di } \\
\text { permukaan maupun struktur } \\
\text { masalah sumber sebagai } \\
\text { kerangka dalam mengajukan } \\
\text { masalah target. }\end{array}$ \\
\hline Iluminasi & $\begin{array}{l}\text { Siswa memperluas dan } \\
\text { mengadopsi informasi yang } \\
\text { dipilih untuk mengontruksi } \\
\text { masalah target. }\end{array}$ \\
\hline Verifikasi & $\begin{array}{l}\text { Siswa mengajukan masalah } \\
\text { berdasarkan ide sebelumnya dan } \\
\text { memeriksa kembali masalah }\end{array}$ \\
& $\begin{array}{l}\text { yang telah diajukan termasuk } \\
\text { mencermati pemecahan } \\
\text { masalahnya. }\end{array}$ \\
\hline
\end{tabular}

\section{HASIL DAN PEMBAHASAN}

Hasil dan Pembahasan mengenai penalaran analogi siswa SMA dalam pengajuan masalah setelah solusi didapat dari proses menganalisis data. Berikut disajikan secara rinci hasil dan pembahasan penelitian ini.

\section{Hasil Penelitian}

Hampir semua subjek $(97,67 \%)$ dapat mengajukan masalah, namun hanya 7 subjek $(16,28 \%)$ yang mampu memecahkan masalah sumber. Secara rinci, hasil pengajuan masalah yang dilakukan oleh 43 subjek dapat dicermati dalam tabel 2.

Tabel 2. Hasil Pengajuan Masalah

\begin{tabular}{|c|c|c|c|}
\hline \multicolumn{3}{|c|}{ Pengajuan Masalah } \\
\hline \multirow{2}{*}{ Kemiripan } & \multicolumn{2}{c|}{ Permukaan } \\
\cline { 2 - 4 } & Tinggi & $19(44,19 \%)$ & $21(48,84 \%)$ \\
\hline \multirow{2}{*}{ Struktur } & Rendah & $0(0 \%)$ & $3(6,98 \%)$ \\
\cline { 2 - 4 } & &
\end{tabular}

Sebagian besar subjek mengajukan masalah dengan memperhatikan informasi di permukaan masalah yaitu: kecepatan bekerja dalam satuan waktu, waktu jeda, dan menanyakan waktu bekerja ketika suatu pekerjaan dilakukan bersama-sama.

\section{Subjek 1}

Salah satu subjek yang mengajukan masalah dengan kemiripan tinggi baik secara permukaan maupun struktur adalah subjek S1. Subjek S1 mengajukan masalah mengenai pengerjaan kamar. Masalah tersebut memberikan informasi mengenai kecepatan masingmasing dari dua orang ketika membangun sebuah kamar. Pada suatu hari, dua orang tersebut melakukan pekerjaan bersama-sama, kemudian selang beberapa hari mereka harus berhenti bekerja, empat hari berikutnya hanya satu 
orang yang melanjutkan pekerjaan hingga selesai pada hari tertentu. Pertanyaan yang diajukan berkaitan dengan waktu mereka berhenti bekerja. Sepintas, masalah yang diajukan S1 mirip dengan masalah mencuci mobil hanya saja konteksnya berbeda. Salah satu kemiripan yang terlihat adalah adanya kecepatan bekerja dan waktu jeda. Secara rinci, masalah yang diajukan oleh subjek S1 dapat dicermati di gambar 3 .

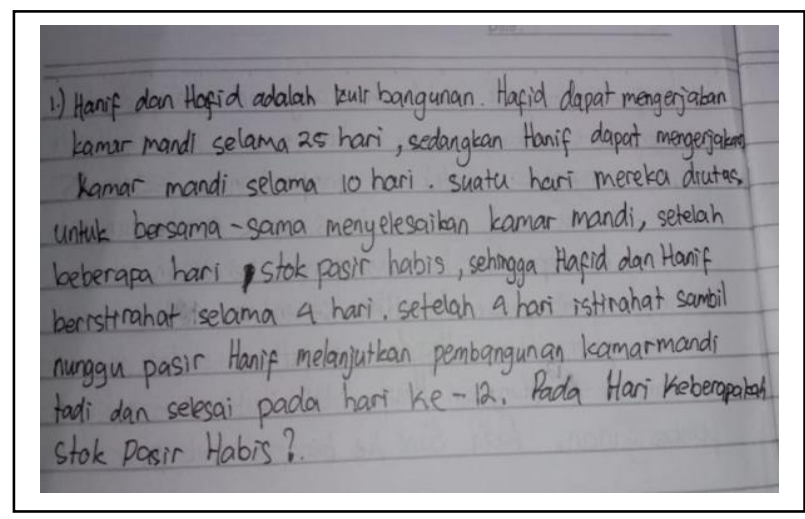

Gambar 3. Pengajuan Masalah oleh Subjek S1

Berdasarkan gambar 3, masalah yang diajukan oleh subjek S1 menanyakan tentang waktu stok pasir habis. Secara permukaan, pertanyaan ini memiliki kemiripan tinggi dengan waktu air tandon habis di masalah mencuci mobil. Selain itu, pernyataan "setelah stok pasir datang, hanya seseorang saja yang melanjutkan pekerjaanya" mirip dengan kondisi setelah air tandon terisi di masalah mencuci mobil. Pemilihan "pasir" secara struktur mirip dengan "air" di masalah mencuci mobil, hal ini dikarenakan fungsi pasir sebagai bahan baku dalam pembangunan seperti air berfungsi sebagai bahan baku mencuci mobil. Secara keseluruhan, penggunaan konteks kecepatan bekerja kemudian munculnya waktu jeda dan kombinasi bekerja antara beberapa orang, mirip dengan masalah mencuci mobil. Sebelum mengajukan masalah, subjek S1 telah memecahkan masalah mencuci mobil dengan benar.

Pemecahan masalah yang dilakukan oleh subjek S1 dapat dikatakan unik, karena menjadi satu-satunya subjek yang dapat memecahkan masalah tanpa mengonversi satuan waktu. Secara umum, subjek S1 memecahkan masalah melalui beberapa langkah yaitu: menuliskan informasi yang diketahui dalam soal (meliputi: kecepatan mencuci, waktu jeda), menghitung waktu yang digunakan selama mencuci mobil, menghitung bagian yang dapat dikerjakan oleh Agung bersama Ardi dan Agung sendiri selama 1 menit menggunakan konsep perbandingan berbalik nilai, memisalkan lama pengerjaan dengan suatu variabel, menyusun model matematika sehingga diperoleh bentuk persamaan linear satu variabel, melakukan operasi sehingga diperoleh nilai variabelnya, kemudian menuliskan jawaban akhir sesuai dengan pertanyaan yaitu waktu ketika tandon air habis. Secara rinci, pemecahan masalah "mencuci mobil" yang dilakukan oleh subjek S1 dapat diamati di gambar 4.

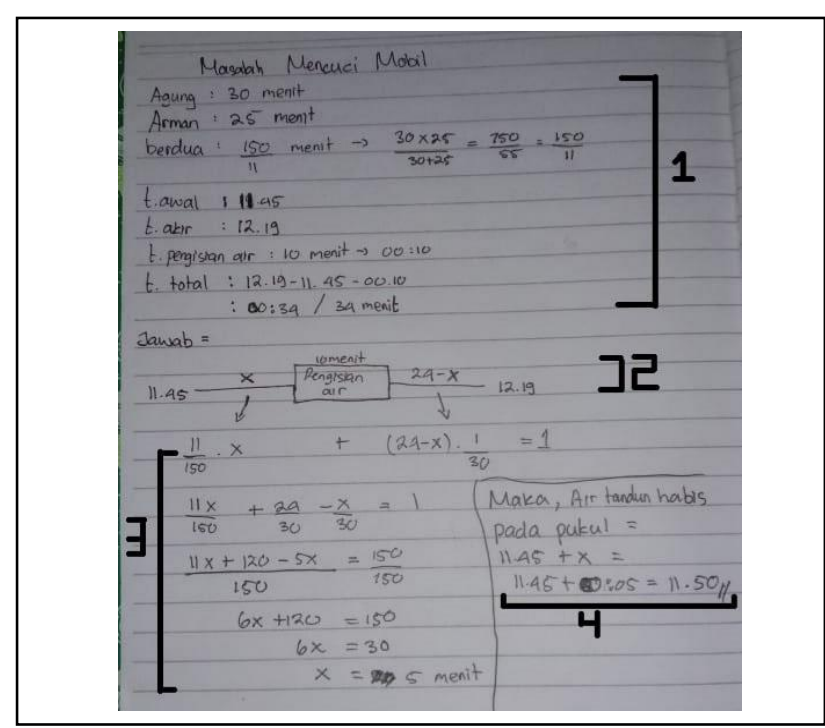

Gambar 4. Pemecahan Masalah Sumber oleh Subjek S1

Berdasarkan gambar 4, subjek S1 menuliskan informasi yang diketahui secara benar (1), subjek S1 membuat sketsa untuk merepresentasikan masalah hanya saja tidak menjelaskan secara eksplisit mengenai variabel yang digunakan (2), subjek S1 memodelkan dan menyelesaikan persamaan linear satu variabel dengan benar (3), subjek S1 menarik kesimpulan secara tepat (4). Selanjutnya, berkaitan dengan penalaran analogi yang terlibat dalam pengajuan masalah, berikut hasil wawancara antara peneliti dengan subjek S1.

P : Berkaitan dengan masalah mencuci mobil, berikan penjelasan mengenai soal tersebut!

S1-01 : Soal itu meminta saya menyelesaikan masalah dua orang yang mencuci mobil pak.

P : Setelah memecahkan masalah mencuci mobil, apakah pekerjaan soal tersebut sudah selesai?

S1-02 : Belum pak, soal itu meminta mengajukan masalah yang mirip dari masalah mencuci mobil.

P : Coba jelaskan mengenai masalah mencuci mobil, informasi apa yang diberikan, ditanyakan, dan termasuk materi apa?

S1-03 : Masalah ini menjelaskan mengenai kecepatan Agung dan Arman dalam mencuci mobil, ketika mereka diminta bekerja sama dan terjadi sedikit masalah (jeda waktu) dilanjutkan Agung sendirian, pertanyaannya adalah waktu yang 
dilakukan oleh Agung dan Arman. Menurut saya, termasuk materi perbandingan berbalik nilai dan persamaan linear satu variabel.

P : Setelah memecahkan masalah mencuci mobil, coba jelaskan proses yang kamu lakukan untuk mengajukan masalah baru!

S1-04 : Pertama, saya melihat kembali masalah mencuci mobil, selanjutnya saya memperhatikan informasi yang diberikan termasuk jeda waktu dan pertanyaannya, kemudian saya memikirkan konteks dan mencoba-coba bilangan sehingga soal saya dapat dikerjakan.

P : Penyelesaian soalmu mirip dengan penyelesaian masalah mencuci mobil, apakah kamu juga memperhatikan prosedur penyelesaian masalah mencuci mobil untuk mengkontruksi soal yang akan kamu ajukan?

S1-05 : Sebenarnya saya lebih melihat soal mencuci mobil, tetapi saya juga melihat jawaban saya, sehingga soal yang saya buat nanti cara menjawabnya sama hanya saja mungkin saya harus mengganti cerita (konteks) dan bilangannya.

P : Coba periksa kembali masalahmu, apakah ada kesalahan?

S1-06 : Tidak pak, menurut saya sudah sesuai pertanyaan juga, jawaban saya juga benar.

P : Menurut kamu, mengapa soal yang kamu buat dapat dikatakan mirip dengan masalah mencuci mobil?

S1-07 : Menurut saya, kedua masalah ini melibatkan (konteks) pekerjaan, melibatkan waktu, cara menjawabnya mirip, terdapat pengecoh waktu jeda, dan materinya juga sama pak.

Berdasarkan wawancara tersebut, pada fase persiapan subjek S1 mengetahui bahwa masalah mencuci mobil harus diselesaikan terlebih dahulu (S1-01), kemudian mengajukan masalah yang mirip dengan masalah mencuci mobil (S1-02).

Pada fase inkubasi, subjek S1 mengidentifikasi informasi di permukaan yaitu: waktu jeda dan pekerjaan (S1-03). Subjek S1 menduga dengan benar, bahwa materi yang terlibat adalah perbandingan berbalik nilai dan persamaan linear satu variabel (S1-03).

Pada fase iluminasi, subjek S1 memilih informasi di permukaan yaitu waktu jeda dan pekerjaan, kemudian mengadaptasi masalah sumber secara langsung untuk memperluas ke konteks baru (S1-04). Walaupun subjek S1 memperhatikan struktur masalah yaitu pertanyaan masalah sumber dan penyelesaiannya, namun subjek S1 menggunakan struktur yang sama (S1-05).

Pada fase verifikasi, subjek S1 mengajukan masalah dengan mengubah konteks menjadi pengerjaan kamar. Selanjutnya, subjek S1 memeriksa kebenaran masalahnya dengan membandingkan kesamaan masalah yang diajukan dan masalah sumber (S1-06). Masalah yang diajukan oleh subjek S1 dapat dipecahkan dengan benar. Secara rinci, pemecahan masalah yang diajukan oleh subjek S1 disajikan dalam gambar 5 .

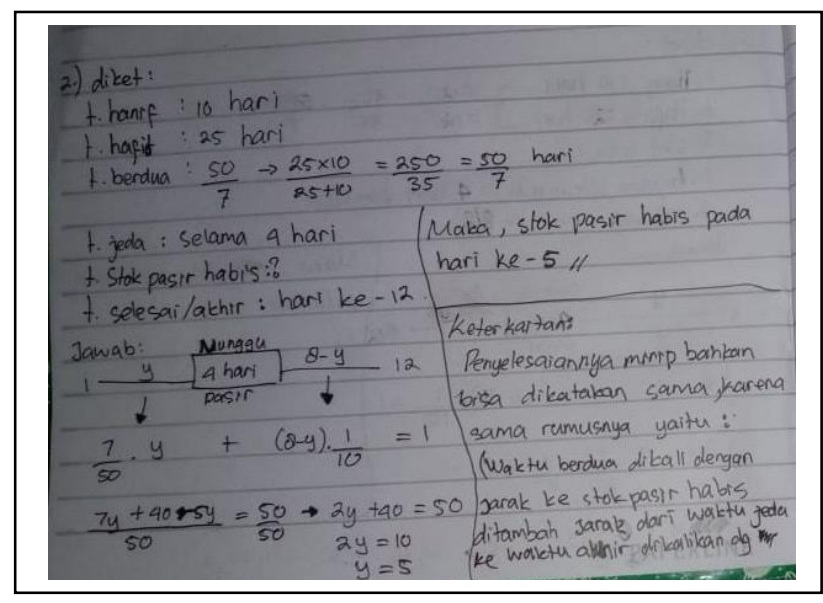

Gambar 5. Pemecahan Masalah Target oleh Subjek S1

Berdasarkan gambar 4 dan gambar 5, dapat diperiksa bahwa dua pemecahan masalah tersebut memiliki kesamaan baik prosedur pemecahan masalah maupun sistematika penulisan. Hal ini terjadi karena secara struktur maupun permukaan kedua masalah tersebut memiliki kemiripan tinggi. Subjek S1 mampu memecahkan masalah sumber, mengajukan masalah, dan memecahkan masalah yang diajukan.

\section{Subjek 2}

Subjek kedua yaitu S2, mengajukan masalah dengan kriteria kemiripan tinggi secara permukaan namun rendah secara struktur. Masalah yang diajukan memiliki kemiripan informasi yang tampak di permukaan yaitu: konteks pekerjaan, waktu bekerja, bekerja bersamaan, dan waktu jeda. Di sisi lain, struktur masalah yang diajukan berbeda dengan masalah mencuci mobil, sehingga prosedur pemecahan masalahnya juga berbeda. Subjek S2 memberikan informasi mengenai dua orang yang akan melihat pertandingan voli pukul 09:00 WIB, suatu ketika ban mereka bocor sehingga harus mencari tambal ban dan menunggunya selama waktu tertentu, salah satu dari mereka melanjutkan perjalanan dan tiba pukul 10.00 WIB. Pertanyaanya adalah pukul berapa mereka berhenti. Secara rinci, masalah yang diajukan oleh subjek S2 disajikan dalam gambar 6. 


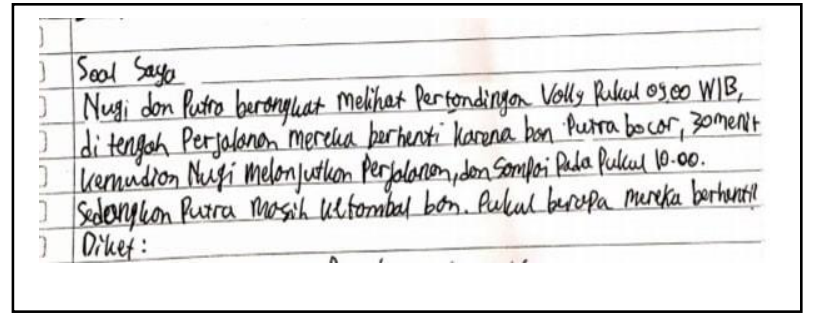

Gambar 6. Pengajuan Masalah oleh Subjek S2

Berdasarkan gambar 6, sekilas terdapat kemiripan antara masalah yang diajukan oleh subjek S2 dengan masalah mencuci mobil. Adanya kejadian berhenti (waktu jeda) dan waktu tempuh perjalanan memiliki kemiripan tinggi dengan waktu melakukan pekerjaan di masalah mencuci mobil. Sebelum mengajukan masalah, subjek S2 telah berusaha memecahkan masalah mencuci mobil, namun pemecahan masalahnya masih kurang tepat. Subjek S2 memecahkan masalah hanya melibatkan konsep pengurangan dan penjumlahan. Secara rinci, pemecahan masalah mencuci mobil yang dilakukan oleh subjek S2 dapat dilihat di gambar 7 .

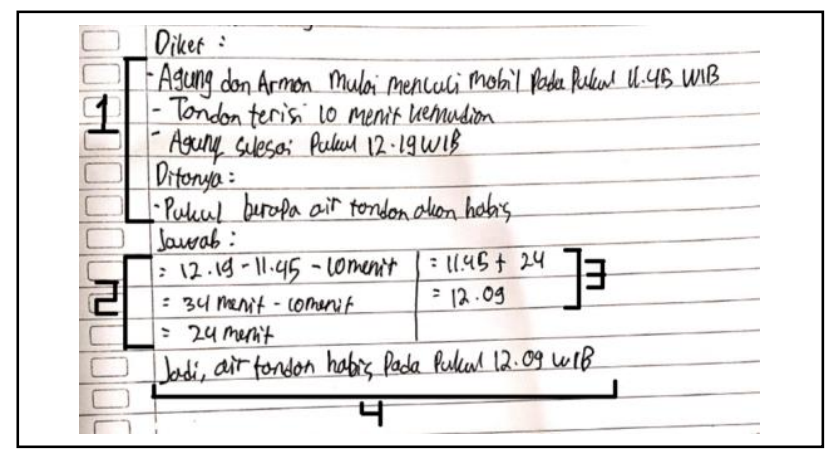

Gambar 7. Pemecahan Masalah Sumber oleh Subjek S2

Berdasarkan gambar 7, tampak bahwa subjek S2 belum menuliskan kecepatan mencuci mobil (1), subjek S2 melakukan penghitungan waktu mencuci mobil dengan benar (2), subjek S2 mengalami miskonsepsi dengan waktu yang ditanyakan (3), akibatnya subjek S2 menarik kesimpulan yang salah (4). Selanjutnya, mengenai penalaran analogi yang terlibat dalam pengajuan masalah, berikut hasil wawancara antara peneliti dengan subjek S2.

P : Berkaitan dengan masalah mencuci mobil, coba berikan penjelasan mengenai soal tersebut!

S2-01 : Soal ini meminta untuk menyelesaikan masalah mencuci mobil dan membuat soal yang mirip pak.
$\mathrm{P} \quad$ : Coba jelaskan mengenai masalah mencuci mobil, informasi apa yang diberikan, ditanyakan, dan termasuk materi apa?

S2-02 : Masalah ini memberikan informasi bahwa tandon terisi 10 menit kemudian, Agung selesai pukul 12:19 WIB, Agung dan Arman mulai mencuci mobil pukul 11:45 WIB, dan menanyakan kapan tandon berhenti. Menurut saya, masalah ini merupakan materi sistem persamaan linear satu atau dua variabel.

P : Sebenarnya kamu mengetahui bahwa melibatkan sistem persamaan linear, namun mengapa di jawabanmu berbeda?

S2-03 : Waktu mengerjakan saya belum kepikiran pak.

P : Setelah memecahkan masalah mencuci mobil, coba jelaskan proses yang kamu lakukan untuk mengajukan masalah baru!

S2-04 : Saya melihat inti soal mencuci mobil, terkait informasi yang ditanyakan yaitu waktu ketika air tandon habis, selanjutnya saya memikirkan tema (konteks) dengan pertanyaan yang melibatkan waktu berhenti.

P : Coba periksa kembali masalahmu, apakah ada kesalahan?

S2-05 : Tidak pak, menurut saya sudah sesuai, karena hanya mengganti tema dan angka.

$\mathrm{P} \quad$ : Menurut kamu, mengapa soal yang kamu buat dapat dikatakan mirip dengan masalah mencuci mobil?

S2-06 : Menurut saya, masalah mencuci mobil menanyakan pukul berapa tandon habis sedangkan soal saya menanyakan pukul berapa mereka berhenti.

Berdasarkan wawancara tersebut, tampak bahwa subjek S2 ketika fase persiapan mengetahui bahwa masalah mencuci mobil harus diselesaikan kemudian mengajukan masalah baru yang mirip (S2-01).

Pada fase inkubasi, subjek S2 mengidentifikasi informasi di permukaan yaitu waktu ketika tandon habis (S2-04). Meskipun subjek S2 mengetahui bahwa masalah sumber melibatkan materi persamaan linear satu variabel (S2-02), namun informasi tersebut diketahui setelah mengumpulkan jawaban (S2-03), sehingga subjek S2 memerlukan waktu lebih lama untuk memahami masalah sumber. Hal ini sesuai dengan gambar 7 (1), bahwa pemecahan masalah mencuci mobil subjek S2 tidak melibatkan persamaan linear satu variabel.

Pada fase iluminasi, subjek S2 memilih informasi waktu berhenti kemudian diperluas ke konteks baru (S2- 
04). Subjek S2 mengadaptasi informasi di permukaan masalah sumber secara langsung.

Pada fase verifikasi, subjek S2 mengajukan masalah dengan mengganti konteks dan memeriksa kebenaran dengan memperhatikan kemiripan antara masalah yang diajukan dan masalah sumber (S2-05). Selanjutnya, subjek S2 dapat memecahkan masalah yang diajukan dengan benar. Pemecahan masalah yang diajukan oleh S2 disajikan dalam gambar 8 .

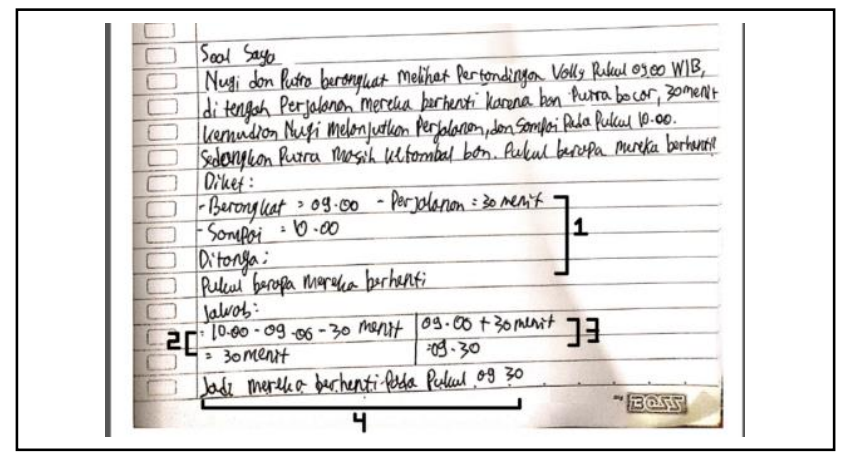

Gambar 8. Pemecahan Masalah Target oleh Subjek S2

Berdasarkan gambar 8, subjek S2 menuliskan informasi masalah dengan benar (1), subjek mengalami kesalahan teknis misalnya mengurangkan waktu yang berbeda satuan (2), subjek melakukan ketidakonsistenan dalam menuliskan satuan (3), subjek S2 menarik kesimpulan secara benar (4). Secara keseluruhan pemecahan masalah yang diajukan S2 benar, dan terlihat mirip dengan pemecahan masalah mencuci mobil (gambar 6 dan 8). Padahal, pemecahan masalah yang diajukan subjek S2 (gambar 8) berbeda dengan pemecahan masalah mencuci mobil yang benar. Hal ini dapat diperiksa dengan membandingkan jawaban subjek S2 (gambar 8) dengan jawaban subjek S1 (gambar 4). Oleh karena itu, sebenarnya subjek S2 mengadaptasi struktur masalah sumber pada fase iluminasi hanya saja terjadi miskonsepsi.

\section{Subjek 3}

Subjek ketiga yaitu S3, mengajukan masalah dengan kemiripan rendah baik secara permukaan maupun struktur. Masalah yang diajukan tidak memiliki informasi yang mirip dengan masalah sumber baik secara tampilan maupun secara struktur. Subjek S3 memberikan informasi mengenai dua siswa yang akan menempuh perjalanan ke sekolah, jarak dari rumah masing-masing siswa ke sekolah diketahui, suatu ketika mereka pergi bersama kemudian seorang siswa memilih jalan pintas sehingga jarak tersebut dapat ditempuh satu menit lebih cepat, pertanyaan yang diajukan terkait dengan waktu tiba di sekolah. Secara rinci, masalah yang diajukan oleh subjek S3 dapat dicermati dalam gambar 9 .

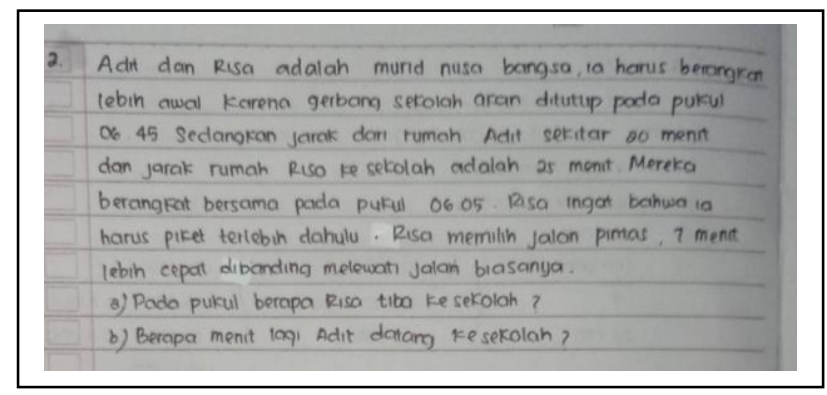

Gambar 9. Pengajuan Masalah oleh Subjek S3

Berdasarkan gambar 9, terdapat kesalahan mendasar pada masalah yang diajukan oleh subjek S3 misalnya penggunaan satuan waktu untuk menyatakan jarak. Sekilas penggunaan kata "menit" merujuk waktu, namun hal ini berbeda dengan masalah yang diajukan subjek S2, konteks waktu di masalah yang diajukan bukanlah waktu jeda atau waktu berhenti, sehingga tidak mirip dengan masalah sumber. Di sisi lain, meskipun masalah yang diajukan subjek S3 memiliki beberapa kesalahan dan memiliki kemiripan rendah secara tampilan maupun struktur, namun subjek S3 mampu memecahkan masalah sumber dengan benar. Pemecahan masalah subjek S3 mirip dengan pemecahan masalah yang dilakukan oleh subjek S1, hanya saja subjek S3 mengkonversi waktu dari satuan menit ke satuan jam. Meskipun hasil konversi waktu menghasilkan bilangan desimal yang lebih rumit, namun subjek S3 mampu memecahkan masalah tanpa melakukan kesalahan kalkulasi. Secara rinci, pemecahan masalah sumber yang dilakukan oleh subjek S3 dapat dicermati dalam gambar 10 .

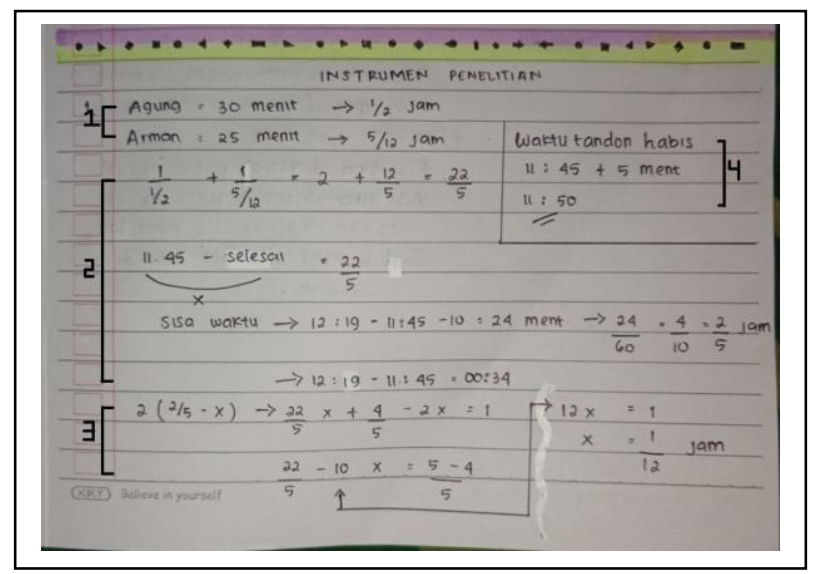

Gambar 10. Pemecahan Masalah Sumber oleh Subjek S3

Berdasarkan gambar 10, subjek S3 mengonversi satuan waktu dari satuan menit menjadi satuan jam (1), subjek S3 menghitung kecepatan mencuci mobil per menit (2), subjek S3 memodelkan dan menyelesaikan dengan benar (3), subjek S3 menarik kesimpulan dengan benar (4). Selanjutnya, terkait dengan penalaran analogi yang terlibat 
dalam pengajuan masalah, berikut hasil wawancara antara peneliti dengan subjek S3.

P : Berkaitan dengan masalah mencuci mobil, coba berikan penjelasan mengenai soal tersebut!

S3-01 : Masalah ini harus diselesaikan pak, dan juga buat soal yang mirip.

$\mathrm{P} \quad$ : Coba jelaskan mengenai masalah mencuci mobil, informasi apa yang diberikan, ditanyakan, dan termasuk materi apa?

S3-02 : Masalah ini memberikan informasi mengenai kecepatan agung dan arman mencuci mobil secara berturut-turut yaitu 30 menit dan 25 menit, serta menanyakan kapan air tandon habis. Menurut saya, materi yang dilibatkan masalah waktu.

$\mathrm{P} \quad$ : Setelah memecahkan masalah mencuci mobil, coba jelaskan proses yang kamu lakukan untuk mengajukan masalah baru!

S3-03 : Saya melihat dan mencoba memahami masalah mencuci mobil, namun saya berusaha untuk membuat soal yang lebih mudah sehingga nanti saya bisa mengerjakannya dengan mudah.

P : Coba periksa kembali masalahmu, apakah ada kesalahan?

S3-04 : Tidak pak, menurut saya sudah sesuai, karena lebih mudah dari masalah mencuci mobil.

P : Menurut kamu, mengapa soal yang kamu buat dapat dikatakan mirip dengan masalah mencuci mobil?

S3-05 : Kemiripannya masalah waktu.

Berdasarkan wawancara tersebut, ketika fase persiapan subjek S3 mengetahui bahwa masalah mencuci mobil memuat dua soal yaitu menyelesaikan masalah mencuci mobil dan mengajukan masalah baru yang mirip (S1-01).

Pada fase inkubasi, subjek S3 mengidentifikasi informasi di permukaan masalah sumber yaitu waktu (S302). Meskipun subjek S3 hanya melihat informasi di permukaan masalah sumber, namun sebenarnya subjek S3 mampu mengidentifikasi struktur masalah sumber yaitu konsep perbandingan berbalik nilai (gambar 10).

Pada fase iluminasi, subjek S3 memperluas informasi permukaan yang diadaptasi yaitu waktu, ke dalam struktur masalah yang lebih sederhana (S3-03). Meskipun mengadaptasi informasi waktu, namun konteks waktu di masalah yang diajukan subjek S2 berbeda dengan konteks waktu di masalah mencuci mobil.

Pada fase verifikasi, subjek S3 mengajukan masalah dengan mengubah konteks dan struktur masalah, serta memeriksa masalah yang diajukan dengan melihat pemecahannya yang lebih mudah dibanding masalah sumber (S3-04). Secara keseluruhan, subjek S3 hanya mengadaptasi informasi di permukaan masalah sumber yaitu waktu. Berdasarkan gambar 9, konteks waktu yang disajikan merupakan satuan dari jarak sehingga berbeda dengan konteks waktu di masalah mencuci mobil. Oleh karena itu masalah yang diajukan oleh subjek S3 memiliki kemiripan rendah baik secara permukaan maupun struktur. Prosedur pemecahan masalah yang diajukan oleh subjek S3 berbeda dengan pemecahan masalah "mencuci mobil" yang dilakukan oleh subjek S3. Subjek S3 memecahkan masalah yang diajukan dengan konsep penjumlahan dan pengurangan. Secara rinci, pemecahan masalah yang diajukan oleh subjek S3 dapat dicermati dalam gambar 11 .

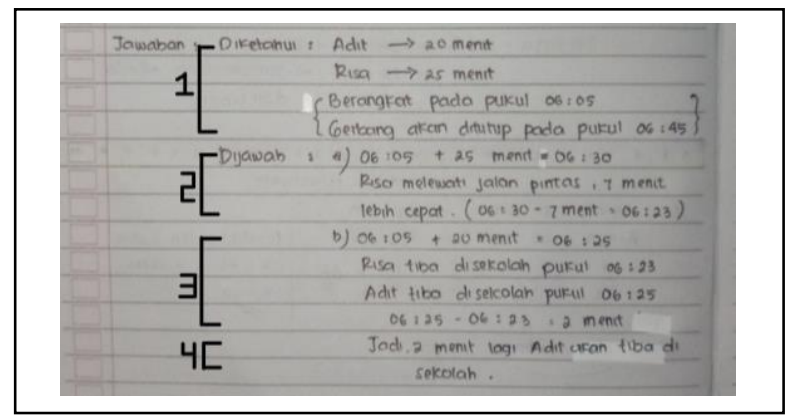

Gambar 11. Pemecahan Masalah Target oleh Subjek S3

Berdasarkan gambar 11, subjek S3 menuliskan informasi yang diketahui dengan benar (1), subjek S3 memodelkan dan menyelesaikannya dengan benar (2 dan 3), subjek menarik kesimpulan dengan benar (4). Meskipun secara keseluruhan pemecahan masalah yang diajukan oleh subjek S3 benar, namun struktur masalah yang diajukan berbeda dengan struktur masalah mencuci mobil. Subjek S3 mengontruksi masalah target dengan struktur dan penyelesaian yang berbeda dengan masalah sumber (gambar 10 dan 11). Oleh karena itu, subjek S3 mengontruksi masalah hanya mengadopsi informasi di permukaan masalah sumber secara langsung, tanpa memperhatikan struktur dan prosedur pemecahan masalah sumber.

\section{Pembahasan}

Berikut disajikan rekapitulasi penalaran analogi yang terlibat ketika siswa mengajukan masalah.

Tabel 3. Rekapitulasi Penalaran Analogi dalam Pengajuan

\begin{tabular}{|c|c|c|}
\hline Subjek & $\begin{array}{c}\text { Tahap } \\
\text { Pengajuan } \\
\text { Masalah } \\
\end{array}$ & Deskripsi \\
\hline Subjek 1 & Persiapan & $\begin{array}{l}\text { Subjek S1 mengetahui } \\
\text { bahwa masalah } \\
\text { harus diselesaikan terlebih } \\
\text { dahulu. }\end{array}$ \\
\hline
\end{tabular}




\begin{tabular}{|c|c|c|}
\hline & & $\begin{array}{l}\text { Subjek S1 mengetahui } \\
\text { bahwa tugas selanjutnya } \\
\text { adalah mengajukan masalah } \\
\text { yang mirip dengan masalah } \\
\text { sumber. }\end{array}$ \\
\hline & Inkubasi & $\begin{array}{lr}\text { Subjek S1 telah } \\
\text { mengidentifikasi } & \text { informasi } \\
\text { di permukaan masalah } \\
\text { sumber yaitu waktu jeda dan } \\
\text { pekerjaan. }\end{array}$ \\
\hline & \multirow[t]{2}{*}{ Iluminasi } & $\begin{array}{lrr}\text { Subjek } & \text { S1 } & \text { memilih } \\
\text { informasi di } & \text { permukaan } \\
\text { yaitu waktu jeda dan } \\
\text { pekerjaan. }\end{array}$ \\
\hline & & $\begin{array}{l}\text { Subjek S1 mengadaptasi } \\
\text { masalah sumber secara } \\
\text { langsung untuk diperluas ke } \\
\text { konteks baru menggunakan } \\
\text { struktur yang sama. }\end{array}$ \\
\hline & \multirow[t]{2}{*}{ Verifikasi } & $\begin{array}{l}\text { Subjek S1 mengajukan } \\
\text { masalah dengan mengubah } \\
\text { konteks menjadi pengerjaan } \\
\text { kamar. }\end{array}$ \\
\hline & & $\begin{array}{lrr}\begin{array}{l}\text { Subjek } \\
\text { kebenaran }\end{array} & \text { memeriksa } \\
\text { dengan } & \text { memalahnya } \\
\text { kesamaan } & \text { masalah yang yang } \\
\text { diajukan } & \text { dan masalah } \\
\text { sumber. } & & \\
\end{array}$ \\
\hline \multirow[t]{8}{*}{ Subjek 2} & \multirow[t]{2}{*}{ Persiapan } & $\begin{array}{l}\text { Subjek } \mathrm{S} 2 \text { mengetahui } \\
\text { bahwa masalah mencuci } \\
\text { mobil harus diselesaikan. }\end{array}$ \\
\hline & & $\begin{array}{l}\text { Subjek } \mathrm{S} 2 \text { mengetahui } \\
\text { bahwa tugas selanjutnya } \\
\text { yaitu mengajukan masalah } \\
\text { yang mirip dengan masalah } \\
\text { sumber. }\end{array}$ \\
\hline & \multirow[t]{2}{*}{ Inkubasi } & $\begin{array}{l}\text { Subjek S2 mengidentifikasi } \\
\text { informasi di permukaan } \\
\text { yaitu waktu ketika tandon } \\
\text { habis. }\end{array}$ \\
\hline & & $\begin{array}{lr}\begin{array}{l}\text { Subjek S2 } \\
\text { kesalahan }\end{array} & \text { mengalami } \\
\text { mengidentifikasi } & \text { dalam } \\
\text { masalah sumber. } & \end{array}$ \\
\hline & \multirow[t]{2}{*}{ Iluminasi } & $\begin{array}{lll}\text { Subjek } & \text { S2 } & \text { memilih } \\
\text { informasi } & \text { waktu } & \text { berhenti } \\
\text { kemudian } & \text { memperluas } \\
\text { konteks baru. } & \end{array}$ \\
\hline & & $\begin{array}{l}\text { Subjek S2 mengadaptasi } \\
\text { informasi di permukaan dan } \\
\text { struktur masalah sumber. }\end{array}$ \\
\hline & \multirow[t]{2}{*}{ Verifikasi } & $\begin{array}{l}\text { Subjek } \quad \text { S2 mengajukan } \\
\text { masalah dengan mengganti } \\
\text { konteks. }\end{array}$ \\
\hline & & $\begin{array}{lrr}\text { Subjek } & \text { S2 } & \text { memeriksa } \\
\text { kebenaran } & \text { dengan } \\
\text { memperhatikan } & \text { kemiripan } \\
\text { antara } & \text { masalah } & \text { yang }\end{array}$ \\
\hline
\end{tabular}

\begin{tabular}{|c|c|c|}
\hline & & $\begin{array}{l}\text { diajukan dan masalah } \\
\text { sumber. }\end{array}$ \\
\hline \multirow[t]{6}{*}{ Subjek 3} & Persiapan & $\begin{array}{l}\text { Subjek S3 mengetahui } \\
\text { bahwa masalah mencuci } \\
\text { mobil memuat dua soal yaitu } \\
\text { menyelesaikan masalah } \\
\text { mencuci mobil dan } \\
\text { mengajukan masalah baru } \\
\text { yang mirip. }\end{array}$ \\
\hline & \multirow[t]{2}{*}{ Inkubasi } & $\begin{array}{l}\text { Subjek S3 } \\
\text { informasi di permukaan } \\
\text { masalah sumber yaitu } \\
\text { waktu. }\end{array}$ \\
\hline & & $\begin{array}{lr}\text { Subjek S3 } & \text { mampu } \\
\text { mengidentifikasi } & \text { struktur } \\
\text { masalah sumber secara tidak } \\
\text { langsung r } \\
\text { memecahkan } & \text { ketika } \\
\text { sumber. } & \text { masalah } \\
\end{array}$ \\
\hline & Iluminasi & $\begin{array}{l}\text { Subjek S3 memperluas } \\
\text { informasi permukaan yang } \\
\text { diadaptasi yaitu waktu, ke } \\
\text { dalam struktur masalah yang } \\
\text { lebih sederhana }\end{array}$ \\
\hline & \multirow[t]{2}{*}{ Verifikasi } & $\begin{array}{lcr}\text { Subjek } & \text { S3 } & \text { mengajukan } \\
\text { masalah } & \text { dengan } & \text { mengubah } \\
\text { konteks } & \text { dan } & \text { struktur } \\
\text { masalah } & \text { menjadi lebih } \\
\text { sederhana. } & & \end{array}$ \\
\hline & & $\begin{array}{l}\text { Subjek S3 memeriksa } \\
\text { masalah yang diajukan } \\
\text { dengan } \\
\text { pemecahannya yang lebih } \\
\text { mudah dibanding masalah } \\
\text { sumber. }\end{array}$ \\
\hline
\end{tabular}

Berdasarkan tabel 3, dapat dicermati bahwa pada fase persiapan siswa mampu memahami maksud masalah sumber dengan benar. Pada fase inkubasi, siswa cenderung mampu mengidentifikasi informasi di permukaan masalah sumber dengan benar. Sementara itu, meskipun siswa mampu mengidentifikasi struktur masalah, namun siswa memerlukan waktu yang lebih lama untuk proses identifikasi tersebut atau ia mengetahuinya secara tidak langsung dalam proses memecahkan masalah sumber. Pada fase iluminasi, siswa cenderung mengadaptasi informasi di permukaan masalah sumber secara langsung. Hasil ini menguatkan argumen English (2004), bahwa masalah sumber dapat diadaptasi secara langsung untuk dipetakan ke masalah target. Siswa cenderung mengubah konteks masalah sumber untuk mengontruksi masalah target.

Dalam mengajukan masalah, siswa cenderung mengadaptasi informasi di permukaan masalah sumber. Hasil ini mirip dengan argumen Gentner dkk. (2007), apabila masalah sumber dan target memiliki sedikit kemiripan secara permukaan maka proses transfer lebih melibatkan proses kognitif siswa. Kondisi tersebut 
mengakibatkan proses mengontruksi masalah menjadi lebih rumit. Hanya saja masalah target dalam penelitian tersebut adalah masalah yang harus dipecahkan, sedangkan dalam penelitian ini masalah target adalah masalah yang diajukan.

Siswa yang mampu mengidentifikasi struktur masalah cenderung mengadaptasi langsung atau mengubah struktur masalah menjadi lebih sederhana dan mengadaptasi informasi di permukaan, namun kesalahan memahami konteks masalah sumber menyebabkan kemiripan permukaannya rendah. Hasil ini sesuai dengan penemuan Schelhorn dalam Gralla (2012), subjek penelitiannya mentransfer pengetahuan dari masalah sumber ke masalah target bahkan tanpa keterkaitan secara permukaan maupun secara struktur.

Ketika mengajukan masalah, siswa cenderung hanya mengubah konteks namun sebagian melakukan kesalahan dalam mengidentifikasi struktur masalah sumber. Hasil ini menguatkan penemuan Manuaba dkk. (2017), bahwa kesalahan dalam penalaran analogi seringkali terjadi ketika memahami struktur masalah sumber. Kesalahan siswa ketika mengidentifikasi struktur masalah sumber berdampak pada hasil proses adaptasi yaitu masalah target yang diajukan. Hal ini sesuai dengan penemuan Kristayulita (2018), bahwa siswa dapat melakukan kesalahan di beberapa proses penalaran analogi yaitu structuring dan applying. Lebih lanjut, ketika siswa gagal mengidentifikasi struktur masalah sumber, akibatnya siswa mengajukan masalah hanya memperhatikan informasi di permukaan masalah sumber. Hasil ini sesuai dengan penemuan Manuaba dkk. (2017), ketika struktur masalah sumber kurang lengkap mengakibatkan siswa gagal mengidentifikasi kemiripan masalah sumber dan target, sehingga siswa lebih fokus pada kemiripan permukaan.

Pada fase verifikasi, siswa memastikan kebenaran masalah yang diajukan dengan melihat masalah sumber dan pemecahan masalah yang diajukan. Keberhasilan siswa dalam mengajukan masalah tidak terlepas dari kemampuannya ketika mengidentifikasi dan memetakan informasi yang ada di masalah sumber baik secara permukaan maupun struktur. Hasil ini mirip dengan temuan Holyoak dan Koh (1987), bahwa struktur masalah dan tampilan permukaan masalah keduanya berperan penting dalam menentukan alternatif solusi dari suatu masalah. Selain itu, kemampuan siswa dalam mengajukan masalah juga tidak terlepas dari keberhasilan siswa tersebut dalam memecahkan masalah sumber atau setidaknya mengetahuinya meskipun secara tidak langsung. Hasil ini menguatkan argumen Kilpatrick dalam Cai (1997) dan temuan baru dari Cai (1997), bahwa kualitas masalah yang diajukan siswa sebanding dengan kemampuannya dalam memecahkan masalah atau setidaknya mengetahui bahwa ia mampu memecahkan masalah tersebut. Oleh karena itu, kemampuan siswa dalam mengidentifikasi informasiinformasi baik di permukaan maupun struktur masalah sumber serta kemampuan siswa dalam mengadaptasikannya ke struktur atau konteks baru dapat membantu siswa dalam mengajukan masalah. Proses mengaitkan suatu masalah dengan masalah sumber dan mengadaptasikannya ke masalah target tersebut dapat ditempuh dengan bantuan penalaran analogi.

\section{PENUTUP}

\section{Simpulan}

Berdasarkan hasil dan pembahasan mengenai penalaran analogi siswa SMA dalam pengajuan masalah setelah solusi maka dapat ditarik kesimpulan sebagai berikut:

1. Siswa yang mengajukan masalah dengan kemiripan tinggi baik permukaan maupun struktur mampu memahami maksud masalah sumber dengan benar (fase persiapan). Siswa mampu mengidentifikasi informasi di permukaan masalah sumber dengan benar namun memerlukan waktu lebih lama dalam mengidentifikasi struktur masalah sumber (fase inkubasi). Siswa mengadaptasi informasi di permukaan dan struktur masalah sumber (fase iluminasi). Siswa memastikan kebenaran masalah yang diajukan dengan melihat masalah sumber dan pemecahan masalah yang diajukan (fase verifikasi).

2. Siswa yang mengajukan masalah dengan kemiripan permukaan rendah namun kemiripan struktur tinggi mampu memahami maksud masalah sumber dengan benar (fase persiapan). Siswa mampu mengidentifikasi informasi di permukaan masalah sumber dengan benar tetapi mengalami miskonsepsi saat mengidentifikasi struktur masalahnya (fase inkubasi). Siswa mengadaptasi informasi di permukaan dan struktur masalah sumber (fase iluminasi). Siswa memastikan kebenaran masalah yang diajukan dengan melihat masalah sumber dan pemecahan masalah yang diajukan (fase verifikasi). Kegagalan siswa dalam mengidentifikasi struktur masalah sumber mengakibatkan ketidakmiripan struktur masalah target hasil adaptasi dengan masalah sumber. Sebenarnya siswa mampu mengidentifikasi struktur masalah sumber, tetapi ia memerlukan waktu yang lebih lama.

3. Siswa yang mengajukan masalah dengan kemiripan rendah baik permukaan maupun struktur mampu memahami maksud masalah sumber dengan benar (fase persiapan). Siswa mampu mengidentifikasi informasi di permukaan masalah sumber dengan benar namun mengetahui struktur masalah sumber secara tidak langsung ketika memecahkan masalah sumber (fase inkubasi). Siswa hanya mengadaptasi informasi di permukaan masalah sumber dan mengubah struktur menjadi lebih sederhana (fase iluminasi). Siswa 
memastikan kebenaran masalah yang diajukan dengan melihat masalah sumber dan pemecahan masalah yang diajukan (fase verifikasi).

4. Berdasarkan uraian tersebut dapat disimpulkan bahwa, ketika mengajukan masalah siswa mampu mengidentifikasi dan mengadaptasi informasi di permukaan maupun struktur masalah sumber. Hanya saja saat mengadaptasi struktur masalah sumber, siswa cenderung membutuhkan waktu yang lebih lama atau ia mengetahuinya secara tidak langsung ketika memecahkan masalah sumber. Selain itu, kemampuan siswa dalam mengidentifikasi (fase inkubasi) dan mengadaptasi (fase iluminasi) informasi yang ada di masalah sumber membantu siswa untuk mengontruksi masalah target. Oleh karena itu, penalaran analogi dapat membantu siswa dalam mengajukan masalah.

\section{Saran}

Berdasarkan pembahasan dan simpulan, peneliti memberikan saran sebagai berikut:

1. Ketika guru menerapkan model pembelajaran berbasis pengajuan masalah tetapi siswa mengalami kesulitan dalam mengajukan masalah maka guru dapat melatihkan siswa untuk mengajukan masalah berbantuan penalaran analogi.

2. Guru perlu melatihkan siswa untuk mengajukan masalah yang tampilannya tidak mirip dengan masalah sumber namun strukturnya mirip berbantuan penalaran analogi. Melalui kondisi tersebut, diharapkan siswa dapat memperluas penerapan dari suatu materi ke konteks yang berbeda-beda.

\section{DAFTAR PUSTAKA}

Afifah, D. S. N. 2015. Profil Pengajuan Masalah Matematika Siswa SMP Berdasarkan Gaya Kognitif. Jurnal Pendidikan dan Pembelajaran Matematika (JP2M), 1(1): 100-111.

Assmus, D., Forster, F, dan Fritzlar, T. 2014. Analogizing During Mathematical Problem Solving-Theoretical and Empirical Considerations. Proceeding of the Joint Meeting of PME 38 and PME-NA 36, 2: 73-80.

Boteanu, A., dan Chernova, S., 2015. Solving and Explaining Analogy Questions Using Semantic Networks. In Proceedings of the Twenty-Ninth AAAI Conference on Artificial Intelligence. Austin: AAAI, 1460-1466.

Brookman-Byrne, Annie, Mareschal, Denis, K., Tolmie Andrew, dan Dumontheil, Iroise. 2019. The Unique Contributions of Verbal Analogical Reasoning and Nonverbal Matrix Reasoning to Science and Math Problem-Solvinf in Adolescence: Relational Reasoning, Science, and Maths. International Mind, Brain, and Education Society and Wiley Periodicals, 13(3): 211-223.
Cai, J. 1997. An Investigation of U.S. and Chinese Students' Mathematical Problem Posing and Problem Solving. Mathematics Education Research Journal, 10, 37-50.

Cai, J., dan Hwang, S. 2002. Generalized and Generative Thinking in US and Chinese Students' Mathematical Problem Solving and Problem Possing. The Journal of Mathematical Behavior, 21(4): 401-421.

Choe, Y. dan Mann, A. 2012. From problem solving to problem posing. Braind-Mind Magazine, 1(1): 7-8.

Cruz, M. 2020. Analogical approach to mathematical problems; discovering relationship between Walter's theorem and Morley's. Latin American Act of Educational Mathematics, 33(1): 175-185.

Cruz, M., Garcia, M. M., Rojas, O. J., dan Sigaretta, J. M. 2016. Analogies in Mathematical Problem Posing. Journal of Science Education, 17(2), 84-90.

English, L. D. 2004. Mathematical and analogical reasoning in early childhood. In L. D. English (Ed.), Mathematical and Analogical Reasoning of Young Learners (pp. 1-22). Mahwah, New Jersey: Lawrence Erlbaum.

Forsyth, B. R. 2018. Defining far transfer via thematic similarity. Cogent Psychology, 5(1): 1-12.

Gentner, D., Loewenstein, J., dan Hung, B. 2007. Comparison fasilitates children's learning of names for parts. Journal of Cognition and Development, 8(3): 285-307.

Gralla, L., Tenbrink, T., Siebers, M., dan Schmid, U. 2012. Analogical Problem Solving: insights from verbal reports. Proceedings of the Annual Meeting of the Cognitive Science Society, 34(34): 396-401.

Holyoak, K. J. 1984. Analogical thinking and human intelligence. In R. J. Stenberg (Ed.), Advances in the psychology of human intelligence (Vol.2). Hillsdale, NJ: Erlbaum.

Holyoak, K. J., dan Koh, K. 1987. Surface and structural similarity in analogical transfer. Memory \& Cognition, 15(4): 332-340.

Hostetter, Autumn B., Penix, Elizabeth A., Norman, Mackenzie Z., Jr., W. Robert Batsell, dan Carr, Thomas H. 2019. The Role of retrieval practice in memory and analogical problem-solving. Quarterly Journal of Experimental Psychology, 72(4): 858-871.

Israel, Nicole. 2019. The Relationship Between Analogical Problem Solving and Analogical Reasoning. Johannesburg: University of the Witwatersland.

Kar, T., Ozdemir, E., Ipek, A. S., dan Albayrak, M. 2010. The relation between the problem-possing and problem-solving skills of prospective elementary mathematics teachers. Procedia-Social and Behavioral Sciences, 2(2): 1577-1583. 
Komalasari, Y., Marlina, N., Ratnapuri, S., dan Amelia, R. 2018. Menganalisis Kemampuan Mathematical Problem Possing pada Mata Pelajaran Matematika Siswa SMA. UNION: Jurnal Pendidikan Matematika, 6(3): 359-368.

Kristayulita, K., Nusantara, T., As'ari, A. R., dan Sa'dijah, C. 2018. Identification of Students Errors in Solving Indirect Analogical Problems Based on Analogical Reasoning Components. Journal of Physics: Conference Series, 1028, 012514.

Kristayulita, K., Nusantara, T., As'ari, A. R., dan Sa'dijah, C. 2020. Schema of Analogical Reasoning - Thinking Process in Example Analogies Problem. Eurasian Journal of Educational Research. 20(88): 87-104.

Kubricht, J. R., Lu, H., dan Holyoak, K. J. 2017. Individual differences in spontaneous analogical transfer. Memory and Cognition, 45: 576-588.

Lee, A. Y. 1992. Analogical reasoning: A new look at an old problem. Boulder, CO: University of Colorado, Institute of Cognitive Science.

Lee, K. H., dan Sriraman, B. 2011. Conjecturing via reconceived classsical analogy. Educational studies in mathematics, 76: 123-140.

Lovett, A., dan Forbus, K. 2017. Modelling visual problem solving as analogical reasoning. Psychological Review, 124(1): 60-90.

Manuaba, Gede Beni, Sutawidjaja, Akbar, dan Susanto, Hery. 2017. Pengkajian Kesalahan Penalaran Analogi Siswa Pra-Kuliah dalam Memecahkan Masalah Berdasarkan Komponen Penalaran Analogi. Prosiding SI MaNIs (Seminar Nasional Integrasi Matematika dan Nilai Islami), 1(1): 278-287.
Purnomo, A., Kartono, dan Widowati. 2015. Model Pembelajaran Problem Posing dengan Pendekatan Saintifik untuk Meningkatkan Kemampuan Pemecahan Masalah. UJMER, 4(1): 49-55.

Rafi, I., dan Sugiman. 2019. Problem Posing Ability Among Prospective Mathematics Teachers. PYTHAGORAS: Jurnal Pendidikan Matematika, 14(2): 188-198.

Richland, L. E., dan Begolli, K. N. 2016. Analogy and Higher Order Thinking: Learning Mathematics as an Example. Policy Insights from the Behavioral and Brain Science, 3(2): 160-168.

Rohmatin, Dian Novita. 2014. Penerapan Model Pembelajaran Pengajuan dan Pemecahan Masalah untuk Meningkatkan Kemampuan Berpikir Kritis Siswa. Gamatika, 5(1): 1-7.

Silver, Edward A., dan Cai, Jinfa. 1996. An Analysis of Arithmetic Problem Posing By Middle School Students. Journal For Research In Mathematics Education, 27(5): 521-539.

Siswono, Tatag Yuli Eko. 2004. Identifikasi Proses Berpikir Kreatif Siswa dalam Pengajuan Masalah (Problem Posing) Matematika Berpandu dengan Model Wallas dan Creative Problem Solving (CPS). Buletin Pendidikan Matematika, 6 (2): 1-16.

Xia, X., U, Chuanhan L., dan Wang, B. 2008. Research on Mathematics Instruction Experiment Based Problem Posing. Journal of Mathematics Education, 1(1): 153-163.

Xie, J., dan Masingila, J. O. 2017. Examining Interactions between Problem Posing and Problem Solving with Prospective Primary Teachers: A Case of Using Fractions. Educational Studies in Mathematics, 96(1): 82-91. 